\title{
PENGARUH POSISI MERANGKAK TERHADAP LAMANYA PROSES PERSALINAN KALA II DI BPM BIDAN N KECAMATAN SAMBONGPARI KOTA TASIKMALAYA
}

\author{
Wulan Puspita Sari $^{{ }^{*}}$, Atit Tadjmiati ${ }^{2}$, Etin Rohmatin ${ }^{3}$ \\ ${ }^{1,2,3}$ Program StudiD4 Kebidanan Poltekes Kemenkes Tasikmalaya \\ *email:wulanps1919@gmail.com
}

\begin{abstract}
ABSTRAK
Angka Kematian Ibu di Indonesia mulai menjadi sorotan terkait sulitnya mencapai target Millennium Development Goals menurunkan Angka Kematian Ibu tahun 2015 menjadi 102 per 100.000 kelahiran hidup dan tahun 2016 berdegenerasi menjadi Sustainable Development Goals Upaya terobosan saat ini sedang dilaksanakan yaitu dengan meningkatkan mutu pelayanan kesehatan bagi ibu dan bayi. Salah satunya posisi persalinan untuk mengurangi rasa sakit pada saat bersalin dan dapat mempercepat proses persalinan. Hasil studi pendahuluan terdapat 18 ibu bersalin pada bulan Juli - Agustus tahun 2016, masalah yang timbul pada kala II terbanyak kelelahan dan kelainan his. Tujuan penelitian mengetahui pengaruh posisi persalinan merangkak terhadap lamanya proses persalinan pada kala II. Pre-eksperimen dengan Static Group Comparison. Populasi semua ibu bersalin primipara 30 orang, teknik sampel Purposive Sampling, Hasil uji statistik dengan menggunakan uji chi square diperoleh nilai $p$ value sebesar 0,016 , jika dibandingkan dengan nilai $\alpha(0,05)$, maka $\mathrm{HO}$ ditolak yang berarti bahwa terdapat pengaruh posisi persalinan merangkak terhadap lama persalinan kala II pada ibu bersalin di BPM Bidan N Kecamatan Sambongpari Kota Tasikmalaya. Berdasarkan hasil penelitian dapat disimpulkan bahwa posisi merangkak memberikan pengaruh terhadap lama persalinan kala II.
\end{abstract}

\section{Kata Kunci : Lama kala II, Posisi merangkak,}

\begin{abstract}
The maternal mortality rate in Indonesia is being spotlighted because of the difficulty of reaching the Millennium Development Goals namely decreasing the maternal mortality rate in 2015 into 102 per 100,000 living births, and in 2016 degenerated into (Sustainable Development Goals). A breakthrough effort that is currently being conducted is improving the health service quality for women and babies, such as the childbirth position to minimize the pain in giving birth and to accelerate the childbirth process. The preliminary study at there were 18 partum women in July-August 2016 and they got the problems of fatigue and abnormal his at the second stage. The purpose of the study was to determine the effect of labor position crawling on the length of labor in the second time. A pre-experiment with Static Group Comparison, was used in this study. The population was 30 partum women, and 28 persons were selected as the sample by using Purposive Sampling. The result of statistical test using chi square showed that the observed significance value $(0.016)$ was smaller than the value of $\alpha$ (0.05), so $\mathrm{H}_{0}$ was rejected. It means, there was an influence of crawling position on the duration of childbirth at the second stage in the work area of Public Health Centre of Sambongpari in Tasikmalaya. Based on the research result, it can be concluded that crawling position influences the duration of childbirth at the second stage.
\end{abstract}

Keywords : Duration of childbirth at the second stage, Crawling position, 


\section{PENDAHULUAN}

Angka Kematian lbu di Indonesia mulai menjadi sorotan terkait sulitnya mencapai target Millennium Development Goals (MDG's yaitu menurunkan Angka Kematian Ibu pada tahun 2015 menjadi 102 per 100.000 kelahiran hidup dan pada tahun 2016 MDGs berdegenerasi menjadi Sustainable Development Goals (SDG'sdengan menargetkan pada tahun 2030, terjadi penurunan rasio kematian ibu yang kurang dari 70 per 100.000 kelahiran hidup (Depkes RI, 2015).

Kementerian Kesehatan $\mathrm{RI}$ telah menetapkan 9 Provinsi prioritas yang memiliki daya ungkit tinggi terhadap program kesehatan nasional, dan diharapkan dapat meningkatkan capaian tujuan pembangunan kesehatan. Provinsi tersebut adalah Jawa Barat, Jawa Tengah, Jawa Timur, Sumatera Utara, Banten, Sumatera Selatan, Lampung, DKI Jakarta dan Sulawesi Selatan (Depkes RI, 2015).

Jawa Barat menduduki peringkat tertinggi dalam menyumbang Angka Kematian lbu sebanyak 823 kasus dan angka kejadian Kematian lbu di Tasikmalaya mencapai 20 kasus serta Kematianlbu terbanyak di Puskesmas Sambongpari sebanyak 3 Kasus, penyebabkematian tersebut adalah perdarahan, eklamsi dan preeklamsia (Dinkes Kota, 2016).

Penyebab langsung kematian ibu adalah perdarahan $(25 \%)$, sepsis $(15 \%)$, hipertensi $(12 \%)$, partus lama $(8 \%)$, abortus (13\%) dan penyebab lain (8\%) (Saifuddin, 2013). Sebagian kematian maternal dan perinatal banyakterjadi pada saat persalinan. Salah satu penyebabnya kala II lama (37\%) dan asfiksia pada bayi (28\%). Penyebab Kala II lama diantaranya posisi saat melahirkan, pimpinan partus yang salah, kelainan his, cara mengejan yang salah sehingga dapat menyebabkan asfiksia pada bayi, kematian janin, inersia uteri, dan kelelahan pada ibu (Widyastuti dkk, 2010).

Penanganan masalah ini tidaklah mudah, oleh karena itu berbagai upaya terobosan saat ini sedang dilaksanakan antara lain dengan meningkatkan mutu pelayanan kesehatan bagi ibu dan bayi melalui peningkatan mutu keterampilan tenaga kesehatan. Sebagai bidan atau petugas kesehatan harus dapat memberikan asuhan sayang ibu selama proses persalinan. Asuhan sayang ibu yang diberikan bisa dalam pemilihan posisi dalam persalinan, salah satunya posisi persalinan untuk mengurangi rasa sakit pada saat bersalin dan dapat mempercepat proses persalinan (Syafrudin, 2012).

Posisi persalinan ibu antara lain posisi duduk atau setengah duduk yang dapat memberikan kenyamanan bagi ibu, posisi jongkok dan posisi berdiri yang membantu mempercepat kemajuan persalinan kala dua dan mengurangi rasa nyeri yang hebat. Posisi miring atau merangkak yang memudahkan ibu untuk beristirahat diantara kontraksi jika ibu mengalami kelelahan dan dapat mengurangi laserasi perineum (Hidayat dan Sujiatini, 2010).

Fenomena yang sering ditemui pada ibu bersalin adalah masih banyak diantara mereka yang belum memahami posisi persalinan dengan baik. Hal ini ditunjukkan dengan posisi meneran dengan terlentang karena tidak tahan sakitnya his persalinan. Banyak perempuan, baik di negara maju maupun di negara berkembang yang melahirkan di sarana pelayanan kesehatan, biasanya tidur dalam posisi telentang (Makuch, 2010). 
Berdasarkan survei dalam jurnal yang dilakukan oleh Joyce,dkk di Amerika Serikat pada tahun 2007 terhadap wanita yang melahirkan, didapatkan bahwa sebanyak $57 \%$ wanitayangmelahirkanpervaginam

menggunakan posisi telentang, 35\% posisi setengah duduk, $4 \%$ posisi jongkok, serta $3 \%$ wanita dengan posisi duduk dan $1 \%$ dengan posisi tangan dan lutut (merangkak) (Joyce et al, 2007).

Menurut Sumarah (2009), bersalin dengan posisi merangkak lebih banyak keuntungan dibandingkan dengan posisi telentang yaitu mengurangi nyeri punggung saat persalinan, dapat membantu perbaikanposisi oksiput yang melintang untuk berputar menjadi posisi oksiput anterior dan dapat mengurangi terjadinya laserasi perineum serta membantu penurunan kepala janin lebih dalam ke dasar panggul. Menurut Gupta dkk, wanita yang melahirkan dengan posisi terlentang lebih merasakan kesakitan, sedangkan dalam posisi tegak kesakitan yang dirasakan lebih ringan (Gufta et al, 2007).

Hasil studi pendahuluan di salah satu BPM wilayah kerja Puskesmas Sambongpari terdapat 18 ibu bersalin pada bulan Juli Agustus tahun 2016 ,didapatkan masalah yang timbul pada kala II terbanyak adalah kelelahan dan kelainan his. Sedangkan yang dilakukan dengan masalah kala II tersebut salah satunya dilakukannya perubahan posisi. Dengan dilakukan perubahan posisi ternyata ada perbaikan yang baik, sehingga bayi lahir spontan. Dari hasil wawancara pada tanggal 13 September 2016 kepada parturien dengan hasil 3 parturien yang mengejan dengan posisi terlentang semuanya mengeluh sangat pegal dan sakit dipunggung bagian bawah.

Berdasarkan data yang ada dan dari hasil penelitian yang sudah diteliti serta dari hasil studi pendahuluan, maka penulis tertarik untuk melakukan penelititan dengan topik "Pengaruh Posisi Persalinan Merangkak Terhadap Lamanya Proses Persalinan Kala II".

\section{METODE PENELITIAN}

\section{Rancangan Penelitian}

Jenis penelitian yang digunakan dalam penelitian ini kuantitatif, desain penelitian pre-eksperimen dengan Static Group Comparison.

\section{Lokasi dan Waktu Penelitian}

Penelitian ini dilaksanakan di BPM Bidan N Kecamatan Sambongpari Kota Tasikmalaya. Penelitian ini telah dilaksanakan pada bulan Desember 2016 - Februari 2017.

\section{Subjek Penelitian}

Populasi dalam penelitian ini adalah ibu bersalin kala II primipara pada bulan Desember 2016 - Februari 2017 di BPM Bidan N Kecamatan Sambongpari Kota Tasikmalaya yang berjumlah 30 orang. Teknik pengambilan sampel dalam penelitian ini adalah menggunakan teknik Purposive Sampling, yaitu teknik pengambilan sampel dengan pertimbangan atau kriteria-kriteria tertentu yaitu ibu bersalin kala II primipara, ibu dengan persalinan normal, ibu bersalin dengan usia kehamilan cukup bulan, TBBJ 2500-3500 gram, dan kondisi ibu baik dan memiliki kemampuan mengedan dengan jumlah sampel sebanyak 28 orang.

\section{Variabel Penelitian}

Variabel independen dari penelitian ini adalah posisi merangkak dan variabel dependen adalah lamanya kala II.

\section{Instrumen Penelitian}


Instrumen yang digunakan pada penelitian ini lembar partograf dan jam tangan yang dilengkapi hitungan detik.

6. Analisa Data

a. Analisis Univariat

Analisis univariat yang digunakan untuk memberikan gambaran distribusi frekuensi dari variabel yang dikaji. Rumus perhitungan persentasenya adalah sebagai berikut :

$\mathrm{P}=\frac{\mathrm{fi}}{\mathrm{N}} \times 100 \%$

Keterangan:

$P$ : persentase

fi : frekuensi teramati

$\mathrm{N}$ : jumlah responden

b. Analisis Bivariat

Untuk mengetahui adanya pengaruh antara variabel yang diteliti maka menggunakan analisis data dengan rumus Chi Square yaitu untuk menguji apakah frekuensi yang terdapat pada masing-masing sampel berada secara signifikan atau hanya kesalahan pengambilan sampel Keputusan dapat dilihat dengan angka probabilitas, dengan ketentuan:

1) Jika nilai $\rho$ value $>\alpha(0.05)$, maka Ho gagal tolak atau $\mathrm{Ha}$ ditolak. Artinya tidak ada pengaruh posisi merangkak terhadap lamanya proses persalinan kala II.

2) Jika nilai $\rho$ value $<\alpha(0.05)$, maka Ho ditolak. Artinya ada pengaruhposisi merangkak terhadap lamanya proses persalinan kala II.

\section{HASIL}

a. Analisis Univariat
1) Posisi Persalinan

Hasil penelitian mengenai pelaksanaan persalinan merangkak dapat dilihat pada tabel di bawah ini :

Tabel 1. Distribusi Frekuensi Posisi Meneran Dengan Merangkak pada Ibu Bersalin di BPM Bidan N Kec. Sambongpari KotaTasikmalaya

\begin{tabular}{ccc}
\hline $\begin{array}{c}\text { Posisi Persalinan } \\
\text { Merangkak }\end{array}$ & Frekuensi & Persentase \\
\hline $\begin{array}{c}\text { Tidak Merangkak } \\
\text { Merangkak }\end{array}$ & 15 & 53,6 \\
\hline Jumlah & 28 & 46,4 \\
\hline Tabel 1 & menunjukkan & bahwa \\
sebagian besar ibu bersalin & tidak \\
melaksanakan posisi merangkak & yaitu \\
sebanyak 15 orang (53,6\%). &
\end{tabular}

Tabel 2. Distribusi Frekuensi Lama Persalinan Kala II pada Ibu Bersalin di BPM Bidan $\mathbf{N}$ Kec. Sambongpari KotaTasikmalaya

\begin{tabular}{|c|c|c|}
\hline $\begin{array}{c}\text { Lama Persalinan } \\
\text { Kala II }\end{array}$ & Frekuensi & Persentase \\
\hline Lebih lama (> 2 jam) & 0 & 0 \\
\hline $\begin{array}{l}\text { Normal }(1,5 \text { jam }-2 \\
\text { jam })\end{array}$ & 11 & 39,3 \\
\hline Lebih cepat $(<1,5$ jam $)$ & 17 & 60,7 \\
\hline Jumlah & 28 & 100 \\
\hline
\end{tabular}

Tabel 2 menunjukkan bahwa lama persalinan kala II pada ibu bersalin di BPM Bidan N Kecamatan Sambongpari Kota Tasikmalaya sebagian besar ada pada kategori lebih cepat $(<1,5$ jam $)$ yaitu sebanyak 17 orang $(60,7 \%)$.

b. Analisis Bivariat

Analisis bivariat digunakan untuk mengetahui pengaruh variabel bebas terhadap terikat, dalam penelitian ini pengaruh posisi persalinan merangkak terhadap lama persalinan kala II. Hasil 
penelitian dapat dilihat pada tabel di bawah ini :

Tabel 3. Tabulasi Silang Pengaruh Posisi Persalinan Merangkak Terhadap Lama Persalinan Kala II di BPM Bidan N Kec. Sambongpari Kota Tasikmalaya

\begin{tabular}{|c|c|c|c|c|c|c|c|}
\hline \multirow{3}{*}{$\begin{array}{c}\text { Posisi } \\
\text { Persalinan } \\
\text { Merangkak }\end{array}$} & \multicolumn{6}{|c|}{$\begin{array}{c}\text { Lama Persalinan } \\
\text { Kala II }\end{array}$} & \multirow{3}{*}{$\begin{array}{c}P \\
\text { value }\end{array}$} \\
\hline & \multicolumn{2}{|c|}{ Normal } & \multicolumn{2}{|c|}{$\begin{array}{l}\text { Lebih } \\
\text { cepat }\end{array}$} & \multicolumn{2}{|c|}{ Total } & \\
\hline & $f$ & $\%$ & $f$ & $\%$ & $f$ & $\%$ & \\
\hline $\begin{array}{c}\text { Tidak } \\
\text { Merangkak }\end{array}$ & 9 & 60.0 & 6 & 40,0 & 15 & 100 & \\
\hline Merangkak & 2 & 15,4 & 11 & 84,6 & 13 & 100 & 0,016 \\
\hline Jumlah & 11 & 39,3 & 17 & 60,7 & 28 & 100 & \\
\hline
\end{tabular}

Berdasarkan Tabel 3 menunjukkan bahwa ibu bersalin yang melaksanakan posisi persalinan tidak merangkak sebanyak 9 orang $(60,0 \%)$ lama persalinan kala II ada pada kategori normal, sedangkan ibu bersalin yang melaksanakan posisi persalinan merangkak sebanyak 11 orang $(84,6 \%)$ lama persalinan kala II ada pada kategori lebih cepat.

Berdasarkan hasil uji statistik dengan menggunakan uji Chi Squarediperoleh nilai $p$ value sebesar 0,016 , jika dibandingkan dengan nilai $\alpha(0,05)$, maka nilai $p$ valuelebih kecildaripada nilai $\alpha(0,016<0,05)$, maka $\mathrm{H} 0$ ditolak yang berarti bahwa terdapat pengaruh posisi persalinan merangkak terhadap lama persalinan kala II pada ibu bersalin di BPM Bidan $\mathrm{N}$ Kecamatan Sambongpari Kota Tasikmalaya.

\section{PEMBAHASAN}

Berdasarkan tabel 1 menunjukkan bahwa sebagian besar ibu bersalin tidak melaksanakan posisi merangkak. Hal ini dikarenakan ibu bersalin lebih terbiasa dengan posisi persalinan selain dengan posisi merangkak salah satunya posisi terlentang, karena masih banyak dari mereka yang belum memahami macam-macam posisi persalinan dengan baik dan masih mengganggap bahwa posisi merangkak itu hal yang aneh bagi mereka untuk proses persalinan.

Pada saat proses persalinan, ibu bersalin primipara tidak bisa mengendalikan rasa nyeri his persalinan sehingga mereka masih banyak yang melakukan posisi terlentang sehingga tidak semua ibu bersalin mau melaksanakan posisi merangkak.

$\mathrm{Hal}$ ini sesuai dengan pendapat (Sumarah, dkk, 2009), tidak ada posisi melahirkan yang paling baik. Masingmasing memiliki kelebihan dan kekurangannya sendiri. Melahirkan bayi ke dunia tidak hanya dapat dilakukan dengan berbaring, tetapi bisa juga dengan berbagai posisi lainnya, salah satunya adalah posisi merangkak.

Posisi merangkak membuat ibu lebih nyaman serta efektif untuk meneran dan memudahkan ibu beristirahat diantara kontraksi, posis merangkak ini sangat cocok untuk persalinan dengan rasa sakit pada punggung.

Ada beberapa pengaruh kemajuan persalinan dengan posisi merangkak ini adalah sebagai berikut :

1. Membantu penurunan lebih dalam ke panggul

2. Dapat meningkatkan perasaan ingin mengedan

3. Efektif untuk mengedan sehingga membutuhkan usaha mengedan yang lebih sedikit dibandingkan dengan posisi berbaring

4. Pada saat persalinan Os Coccygis menghadap ke atas sehingga dapat memperluas jalan lahir

5. Membantu janin dalam melakukan rotasi 
6. Membuat ibu lebih nyaman serta mengurangi rasa sakit pada punggung.

Dari tabel 2 dapat diketahui lama persalinan kala II pada ibu bersalin lebih cepat $(<1,5$ jam). Hal ini sesuai dengan pendapat Mochtar (2013), pada kala pengeluaran janin, his terkoordinasi, kuat, cepat dan lebih lama, kira-kira 2-3 menit sekali. Kepala janin telah turun dan masuk ke ruang panggul sehingga terjadilah tekanan pada otot-otot dasar panggul yang melalui lengkung refleks menimbulkan rasa mengedan. Karena tekanan pada rektum, ibu merasa seperti mau buang air besar, dengan tanda anus terbuka.

Pada waktu his, kepala janin mulai kelihatan, vulva membuka dan perineum meregang. Dengan his dan mengedan yang terpimpin, akan lahir kepala, diikuti oleh saluran badan janin. Kala II pada primi berlangsung selama 1 1/2 - 2 jam dan pada multi $1 / 2-1$ jam.

Berdasarkan Tabel 3 menunjukkan bahwa terdapat pengaruh posisi persalinan merangkak terhadap lama persalinan kala II. Dari hasil penelitian menunjukka bahwa ibu bersalin yang melakukan posisi persalinan merangkak lama persalinannya lebih cepat. Ini terjadi karena dengan posisi persalinan merangkak dapat mempercepat penurunan kepala janin lebih dalam ke dasar panggul dan ibu lebih mudah meneran. Ibu bersalin mengungkapkan bahwa dengan posisi merangkak ibu lebih santai dan nyaman dengan posisi yang telah diajarkan oleh peneliti.

Hasil uji statistik menunjukan nilai $p$ value lebih kecil daripada nilai $\alpha(0,016<$ $0,05)$, yang berarti bahwa terdapat pengaruh posisi persalinan merangkak terhadap lama persalinan kala II pada ibu bersalin di BPM
Bidan N Kecamatan Sambongpari Kota Tasikmalaya.

Adanya pengaruh ini menunjukan bahwa faktor teknik meneran dengan posisi merangkak secara signifikan memiliki pengaruh dengan lama persalinan kala II. Hubungan yang terjadi adalah hubungan sejajar dimana semakin banyak ibu yang melakukan teknik meneran dengan posisi merangkak maka cenderung persalinan kala II semakin cepat, sebaliknya jika posisi meneran dengan posisi tidak merangkak salah satunya posisi terlentang maka cenderung memiliki waktu persalinan kala II yang lama.

Hal ini sesuai dengan pendapat Hidayat dan Sujiatini (2010), bahwa keuntungan dari posisi persalinan merangkak yaitu, memudahkan ibu untuk beristirahat diantara kontraksi jika ibu mengalami kelelahan dan dapat mempercepat kemajuan persalinan kala II serta dapat mengurangi laserasi perineum. Hal ini menunjukkan bahwa dengan posisi persalinan merangkak dapat membantu ibu untuk beristirahat.

Setelah memantau persalinan dengan posisi merangkak, peneliti tidak menemukan komplikasi yang diakibatkan oleh intervensi tersebut. Sehingga dalam penerapan Asuhan Persalinan Normal (APN) yang merupakan upaya terintegrasi dan lengkap.

\section{SIMPULAN DAN SARAN}

\section{Simpulan}

a. Lama persalinan kala II ibu bersalin di BPM Bidan N Kecamatan Sambongpari Kota Tasikmalaya yang melakukan posisi persalinan merangkak ada pada kategori lebih cepat sebesar $84,6 \%$. 
b. Lama persalinan kala II ibu bersalin di BPM Bidan N Kecamatan Sambongpari Kota Tasikmalaya yang tidak melakukan posisi persalinan merangkak ada pada kategori normal sebesar $60,0 \%$.

c. Terdapat pengaruh posisi persalinan merangkak terhadap lama persalinan kala II pada ibu bersalin di BPM Bidan $\mathrm{N}$ Sambongpari Kota Tasikmalaya dengan nilai $p$ value sebesar 0,016 .

2. Saran

Bagi profesi kebidanan hendaknya melakukan pendekatan persuasif kepada ibu bersalin, tentang berbagai macam posisi persalinan terutama posisi persalinan merangkak, sebagai salah satu posisi persalinan yang dapat mempercepat lama persalinan kala II.Selain itu hendaknya pihak puskesmas melalui petugasnya memberikan sosialisasi kepada masyarakat terutama kepada ibu hamil tentang manfaat posisi merangkak, sehingga pada saat persalinan ibu bersedia dan tidak merasa cemas untuk melakukan posisi persalinan merangkak.

\section{DAFTAR PUSTAKA}

Dinas Kesehatan Kota Tasikmalaya. 2016. Profil Kesehatan Dinas Kesehatan Kota Tasikmalaya 2015. Dinkes Tasikmalaya.

Gupta JK, Hofmeyr GJ, Smyth RMD. 2007. Position in the second stage of labour for women without epidural anaesthesia. Tersedia dari:
Hidayat. A. M., Sujiyatini. 2010. Asuhan Kebidanan Persalinan. Yogyakarta : Nuha Medika IImu.

Departemen Kesehatan. 2015. Profil Kesehatan Indonesia. Depkes RI, Jakarta.

Joyce T. DiFranco, Amy M. Romano, Ruth Keen. 2007. Spontaneous Pushing in Upright or Gravity-Neutral Positions. Tersedia dari: www.ncbi.nlm.nih.gov.diakses tanggal 2 September 2016.

Makuch MY. 2010. Maternal positions and mobility during first stage of labour: tersedia dari: www.who.int/rhl/pregnancy childbirth/c hildbirth/en.Diakses tanggal 2 September 2016.

Rustam Mochtar. 2013. Sinopsis Obstetri. EGC. Jakarta.

Saifuddin, Abdul Bari. 2013. Ilmu r in. Bina Pustaka Sarwono Prav jo. Jakarta.

Sumarah. 2009. Perawatan lbu Bersalin (Asuhan Kehamilan Pada Ibu Bersalin). Fitramaya. Yogyakarta.

Syafrudin., Hamidah., 2012, Kebidanan Komunitas, Jakarta : Penerbit Buku Kedokteran EGC.

Widyastuti, dkk. 2010. Kesehatan Reproduksi .Yogyakarta: Fitramaya. http://www.thecochranelibrary.com, diakses tanggal 2 September 2016. 